\title{
Infeksjoner i sår som er suturert på legevakt
}

\begin{abstract}
BAKGRUNN Ulike tradisjoner preger sårbehandlingen i forskjellige land. Vi har undersøkt forekomst og ulike faktorer knyttet til infeksjoner i sårskader behandlet med sutur ved en norsk legevakt.
\end{abstract}

MATERIALE I denne prospektive studien registrerte vi kliniske data om 102 pasienter med sårskader som ble suturert ved Bergen legevakt i perioden 16.2.-30.6. 2011. Eventuelle infeksjoner ved suturfjerning ble vurdert og gradert etter alvorlighetsgrad på en skala fra 1 til 4 hos 97 av disse pasientene.

RESULTATER Ingen fikk alvorlig infeksjon, men $15 \%$ utviklet lettere kliniske sårinfeksjoner - $11 \%$ grad 1-infeksjon og $4 \%$ grad 2-infeksjon. Pasienter under 65 år hadde ofte skadet seg på kniv ( $n=33,37 \%)$ og i hånden ( $n=60,67 \%)$. Menn skadet seg oftest på arbeidsplassen ( $n=38,54 \%$ ) og kvinner oftest hjemme ( $n=18,56 \%$ ). Vi fant ikke statistisk signifikant sammenheng mellom sårinfeksjon og sårets lengde, tidsintervall før suturering, lokalisering på kroppen, forurensning eller underliggende kronisk sykdom. To av tre pasienter med selvskading fikk sårinfeksjon. I bakteriologisk prøve fra ti av 15 sår med klinisk infeksjon var det i halvparten rikelig oppvekst av gule stafylokokker. Én pasient fikk peroral antibiotikabehandling på grunn av sårinfeksjon og to fikk lokalbehandling med antibiotika.

FORTOLKNING Lettere kliniske sårinfeksjoner forekom i nesten ett av seks sår suturert på legevakt. Flere studier er ønsket for å kunne gi oss bakgrunnsdata for målrettede forbedringer av sårskadebehandlingen i primærhelsetjenesten.

Sårbehandlingen i forskjellige land er preget av ulike tradisjoner og retningslinjer. Mange steder er det vanligere enn det er i Norge med bruk av antibiotikaholdige sårsalver og bredspektret peroral antibiotikabehandling $(1,2)$. De fleste studier av suturerte traumatiske sårskader utenfor sykehus omhandler derfor effekten av forskjellige antibiotikaholdige sårsalver. Sårinfeksjonsratene har variert fra $1 \%$ til $31 \%$ i slike materialer (3-7).

Definisjonen av infeksjon i suturerte sårskader brukes ikke konsekvent i alle studier, og dette gjør sammenlikninger vanskelig. Det er derfor viktig at det gjøres nasjonale studier der man tar hensyn til både lokale tradisjoner og gjeldende faglig baserte retningslinjer og definisjoner.

I dag eksisterer det gode registre over infeksjonsrater i suturerte operasjonssår behandlet i sykehus. I norske sykehus varierer hudinfeksjonshyppigheten i suturerte operasjonssår fra $4 \%$ (innsetting av hofteprotese) til $18 \%$ (operasjoner på tykktarm) (8). Slike registre gir god bakgrunnsinformasjon for å kunne gjøre målrettede forbedringer, men benyttes foreløpig lite for traumatiske sår behandlet utenfor sykehus. Egne registreringsskjemaer for dette formålet er imidlertid utviklet og validert i USA (4), men er foreløpig lite brukt.

Vi er ikke kjent med at det foreligger publiserte studier der man har sett på andelen infeksjoner i suturerte sårskader behandlet ved norske legevakter. Formålet med denne studien var derfor å kartlegge forekomsten av sårinfeksjoner ved en stor norsk legevakt.

\section{Materiale og metode}

Studien ble utført i perioden 16.2.-30.6. 2011. Alle pasienter over 18 år som oppsøkte Bergen legevakt med traumatiske sårskader som omfattet delhud eller fullhud der det ble funnet indikasjon for sårlukking med sutur, ble vurdert for inklusjon. Ekslusjonskriteriene var følgende: Sår eldre enn åtte timer (i ansiktet $12 \mathrm{t}$ ), bittskader, dype sår med tilleggsskader i beinvev, sener, nerver eller større kar, manglende samtykkekompetanse hos pasienten, manglende mulighet for å komme tilbake til sårkontroll og bruk av peroral antibiotikabehandling den siste uken før sårskaden.

Sårskadepasienter som kom til behandling om natten, var ofte påvirket av rusmidler, noe som reduserte deres evne til å gi samtykke til deltakelse $i$ en studie og følge avtaler om sårkontroll og suturfjerning. Vi valgte derfor å inkludere kun pasienter som ble behandlet på dag- og kveldstid. Av tidsmessige årsaker ble inklusjonsperioden begrenset til 4,5 måneder. Styrkeberegning ble ikke utført før oppstart av studien. sis, i henhold til egen metodebok som var basert på Legevakthåndboken (9), ble fulgt i sårbehandlingen og $\mathrm{i}$ behandlingen $\mathrm{av}$ en eventuell sårinfeksjon. Ved akutte skader ble såret rengjort med sterilt saltvann. Intakte hudområder rundt såret ble desinfisert med klorheksidinsprit før steril oppdekning til suturering. Sår med forurensning ble mekanisk renset med tupfere eller sterile børster. Nekrotisk vev ble revidert før suturering.
Bergen legevakts vanlige kliniske prak-

\author{
Christina Brudvik \\ christina.brudvik@k1.uib.no \\ Klinisk institutt 1 \\ Universitetet i Bergen \\ og \\ Bergen legevakt \\ og \\ Fana legekontor \\ Hina Tariq \\ Jølster legekontor \\ Skei i Jølster
}

Soosaipillai V. Bernardshaw

Bergen legevakt

Knut Steen

Bergen legevakt

og

Nasjonalt kompetansesenter for legevaktmedisin

Artikkelen er basert på en studentoppgave ved Det medisinsk-odontologiske fakultet, Universitetet i Bergen.

Engelsk oversettelse på www.tidsskriftet.no

\section{HOVEDBUDSKAP}

Lette sårinfeksjoner forekom i $15 \%$ av sårskader suturert på legevakt

Det var høyest antall sårskader, men lavest prosentandel sårinfeksjoner på hender og ansikt sammenliknet med andre deler av kroppen

Flere og større studier er ønskelig for å kunne gi oss bakgrunnsdata for målrettede forbedringer av sårskadebehandlingen i primærhelsetjenesten 
Tabell 1 Faktorer som ble registrert ved første konsultasjon

\begin{tabular}{|c|c|c|}
\hline Pasientfaktorer & Sårfaktorer & Behandlingsfaktorer \\
\hline Alder & Størrelse & $\begin{array}{l}\text { Desinfeksjon, sårrensing } \\
\text { eller revisjon før suturering }\end{array}$ \\
\hline Kjønn & Lokalisering & Antall suturer \\
\hline Kronisk sykdom & Antall timer før behandling på legevakten & Lokal eller peroral antibiotika \\
\hline Faste medisiner & $\begin{array}{l}\text { Forurensing med fremmedlegemer } \\
\text { (jord, småstein, rust eller liknende) }\end{array}$ & \\
\hline Graviditet & $\begin{array}{l}\text { Skademekanismer, inklusive redskap } \\
\text { og skadested }\end{array}$ & \\
\hline
\end{tabular}

Sutureringen ble utført av den lege som til enhver tid hadde vakt på Bergen legevakts såravdeling. Enkeltstående suturer ble brukt, med varierende trådtykkelse, avhengig av skadens lokalisering og sårets størrelse. I ansiktet ble det benyttet tynnest tråd, tykkelse 5-0, og suturfjerning etter fem dager, mens det over strekkesteder og rygg ble benyttet trådtykkelse 3-0 eller 4-0 og suturfjerning etter $12-14$ dager. Andre steder på kroppen ble suturene fjernet etter ti dager. Ikke-resorberbar monofilamenttråd av nylon (Ethilon) ble brukt. Rene sårskader på under to centimeters lengde, med lite diastase og lite strekk i vevet rundt skaden, ble adaptert med tape eller vevslim. Disse skadene ble derfor ikke inkludert i studien.

Vi benyttet semistrukturerte spørreskjemaer med både avkrysning og fritekst. Informasjon om pasientfaktorer ble fylt ut av pasienten selv ved første konsultasjon på Bergen legevakt. Behandlende lege eller sykepleier eller begge fylte ut informasjon om sårfaktorer og behandlingsfaktorer ved denne konsultasjonen ( $\operatorname{tab} 1$ ).

Pasientene fikk tildelt time til suturfjerning ved Bergen legevakt. Ved denne kontrollen ble det spesifikt vurdert om det forelå en sårinfeksjon. Basert på en internasjonalt benyttet og validert klassifisering $(3,4)$ graderte behandlende lege sårinfeksjon på følgende måte:

Grad 0: ingen tegn til infeksjon

Grad 1: enkle pusslommer i sting (pustler/ suturabscesser) og eventuelt rødhet med radius under $1 \mathrm{~cm}$

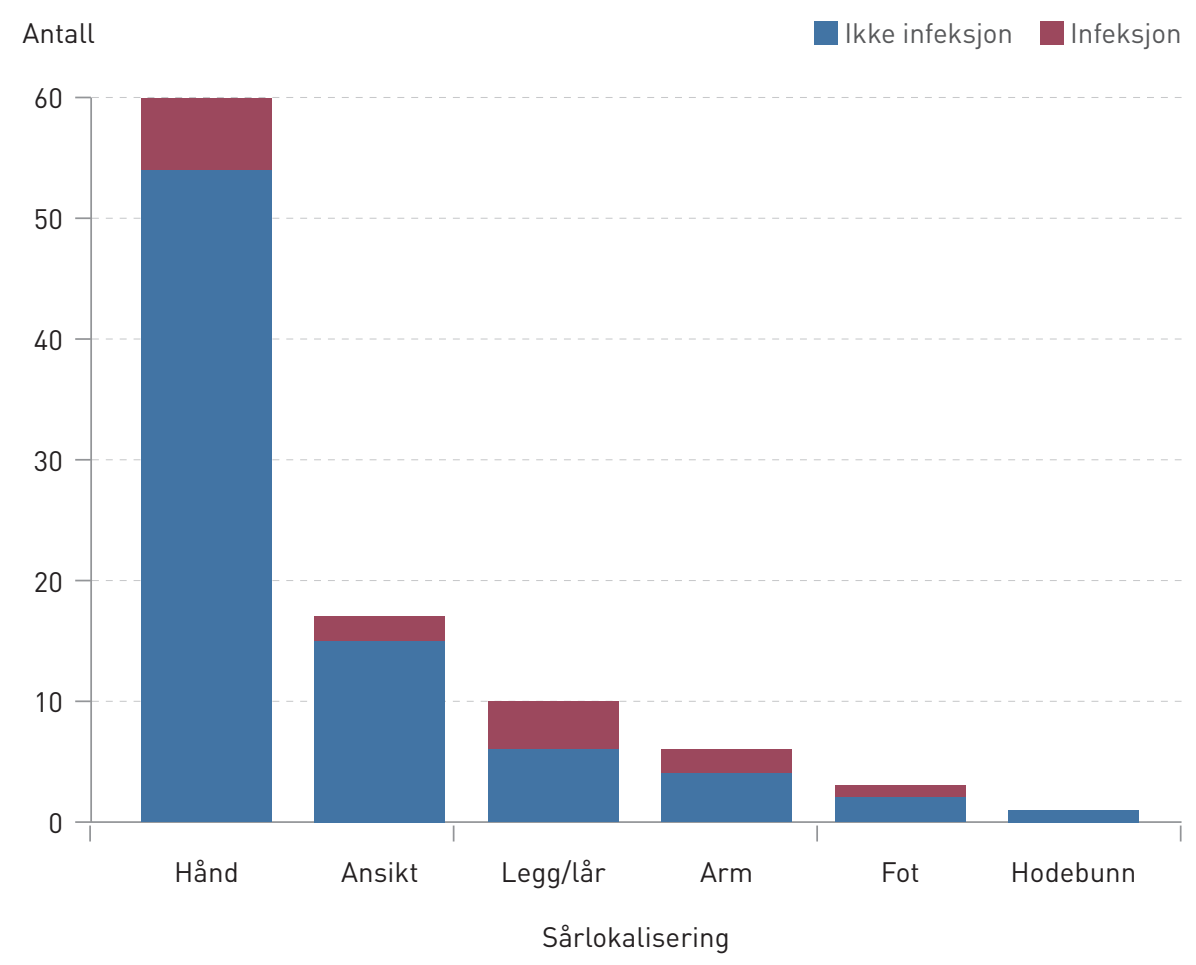

Figur 1 Antall sårinfeksjoner etter sårlokalisering i 97 sår suturert ved Bergen legevakt i perioden februar til juni 2011
Grad 2: rødhet/hevelse omkring sår med radius over $1 \mathrm{~cm}$ (cellulitt)

Grad 3: rød stripe og/eller ømme lymfeknuter (lymfangitt/lymfadenitt)

Grad 4: feber og frostanfall (systemiske symptomer)

I henhold til studieprotokollen skulle bakteriologisk prøve med resistensbestemmelse tas i tilfelle kliniske tegn på sårinfeksjon (dvs. infeksjonsgrad 1 eller høyere). Ved mangelfullt utfylte skjema søkte vi i legevaktjournalen til de inkluderte pasientene for å supplere med data vedrørende den aktuelle sårskaden. Ved manglende oppmøte for suturfjerning kontaktet vi pasienten per telefon og graderte en eventuell sårinfeksjon ut fra pasientens egne opplysninger.

Dataene fra spørreskjemaene ble registrert og bearbeidet i SPSS statistikkprogram versjon 17. Deskriptiv statistikk ble benyttet i beskrivelsen av sårskadene. Et signifikansnivå på $5 \%$ ble valgt $(p \leq 0,05)$. Vi benyttet Pearsons khikvadrattest i krysstabell for å sammenlikne grupper og Fishers eksakte test når én eller flere celler inneholdt færre enn fem pasienter.

Studien er godkjent av regional etisk komité (REK Vest).

\section{Resultater}

I løpet av studieperioden fylte 103 pasienter inklusjonskriteriene. Én ønsket ikke å delta, slik at 102 pasienter ble inkludert, hvorav 70 menn og 32 kvinner. Pasientenes gjennomsnittsalder var 37,7 år (spredning 18-87 år). Sårene var gjennomsnittlig 2,4 timer gamle (spredning 0,5-10 t). Gjennomsnittlig sårlengde angitt av lege eller sykepleier var 3,0 $\mathrm{cm}$ (spredning 1-13 cm). Gjennomsnittlig antall suturer per pasient var 4,1 (spredning 1-11). Hos én pasient ble sårskaden også adaptert med subkutant plassert resorberbar sutur.

Rundt én av tre skadet seg på kniv. Selvskading var årsak til tre av sårskadene, én skyldtes vold, mens resten skyldtes uhell. 72 hadde selv prøvd å rengjøre og bandasjere sårskaden før de tok kontakt med legevakten. 46 pasienter hadde sår som var forurenset med fremmedlegemer. De fleste sår var lokalisert til hender og ansikt (fig 1). Åtte pasienter hadde kronisk sykdom og/eller brukte faste medikamenter som kunne påvirke risikoen for sårinfeksjoner eller sårkomplikasjoner (diabetes, immunsupprimerende eller antikoagulerende behandling eller liknende).

De fleste pasienter under 65 år skadet seg på kniv $(\mathrm{n}=33,37 \%)$ og $\mathrm{i}$ hånden $(\mathrm{n}=60$, $67 \%$ ), mens de fleste eldre skadet seg mot asfalt/trapp/stein $(\mathrm{n}=4,50 \%)$ og i ansiktet $(\mathrm{n}=5,63 \%)$. Menn skadet seg oftere på arbeidsplassen $(\mathrm{n}=38,54 \%)$ og kvinner oftere i hjemmet $(n=18,56 \%)$. Signifikant 
flere menn enn kvinner skadet seg på arbeidsplassen $(p<0,001)$.

Seks pasienter fikk forskrevet forebyggende peroral antibiotikabehandling etter suturering, men ingen fikk lokalbehandling med antibiotikakrem eller salve.

Suturene ble fjernet etter gjennomsnittlig 10,5 dager (spredning 5-15 d). 82 pasienter møtte opp for suturfjerning ved Bergen legevakt slik at vi fikk vurdert og gradert eventuelle kliniske sårinfeksjoner. 20 pasienter møtte ikke, men vi fikk telefonisk kontakt med 15 av disse, gjennomsnittlig 15 uker (spredning 4-34 uker) etter suturering. Vi klarte ikke å skaffe opplysninger om de fem resterende pasientene. Totalt registrerte vi 15 infeksjoner av de 97 suturerte sårskadene $(15 \%)$ som vi kunne vurdere, hvorav tre var beskrevet av pasientene selv i telefonintervju.

$11(11 \%)$ sår ble klassifisert som grad 1infeksjon og fire (4\%) som grad 2-infeksjon. Det var ingen grad 3- eller grad 4-infeksjon. En pasient med grad 1-infeksjon i en finger fikk peroral antibiotikabehandling med dikloksacillin etter at suturene var fjernet. To pasienter med henholdsvis grad 1- og grad 2infeksjon fikk lokalbehandling med antibiotikaholdig krem (bacimycin og fusidinsyre). De resterende fikk ingen form for antibiotikabehandling.

Vi fant lavest prosentandel infeksjoner i sår på hender $(\mathrm{n}=6,10 \%)$ og $\mathrm{i}$ ansikt $(\mathrm{n}=2$, $12 \%)$. Andelen infeksjoner i sårskader på overekstremitetene utenom hendene og på underekstremitetene var høyere, henholdsvis $33 \%(n=2)$ og $38 \%(n=5)$ (fig 1). Det var ingen signifikant forskjell i infeksjonsrisiko mellom sårlokalisering $\mathrm{i}$ ansikt og hode versus ekstremiteter ( $\operatorname{tab} 2$ ).

Tre pasienter hadde sårskader forårsaket av selvskading. To av disse utviklet en sårinfeksjon grad 2.

Det ble tatt bakteriologisk prøve av ti av de 15 sårene der det var klinisk infeksjon. I to ble det kun påvist normal hudflora og hos to var det ingen vekst av bakterier. I fem var det rikelig vekst av Staphylococcus aureus og i det sjette gramnegative staver. Resistensbestemmelse av de gule stafylokokkene viste penicillinresistens hos fire av fem.

Vi så etter eventuelle forskjeller i infeksjonsrate mellom sårskader som ble suturert innen tre timer etter at skaden hadde skjedd og skader som ble suturert senere, men fant ingen signifikant forskjell ( $\operatorname{tab} 2$ ). Det var heller ingen forskjell når det gjaldt sår som ble klassifisert som rene og sår som var forurenset før sårbehandlingen. Likeledes var det ingen signifikant sammenheng mellom risiko for sårinfeksjon og pasientens alder eller kjønn eller tilstedeværelse av kroniske sykdommer. Av de seks pasientene som fikk profylaktisk peroral antibiotikabehandling etter suturering på grunn av initialt foruren- set sår, fikk én klinisk infeksjon grad 1. Bakteriologisk prøve viste imidlertid ikke oppvekst av bakterier.

\section{Diskusjon}

Dette er den første norske studien der man har undersøkt kliniske sårinfeksjoner i suturerte traumatiske sår behandlet på legevakt. Hvert år blir over 33000 sårskader suturert primærhelsetjenesten i Norge (10). Basert på en internasjonalt benyttet definisjon og alvorlighetsgradering fant vi at $15 \%$ av pasientene fikk sårinfeksjon, men ingen av alvorlig karakter. I studier fra USA og England der man har benyttet den samme sårinfeksjonsgraderingen $(3,4)$, varierte andelen infeksjoner mellom 3,5\% og $18 \%$, men både lokal og peroral forebyggende antibiotikabehandling ble benyttet oftere enn hos oss.

I den ene studien (4) hadde de pasientene som fikk antibiotikaholdig lokalbehandling lavest infeksjonsrate $(4,5 \%)$, mens de som ikke fikk hadde en infeksjonsrate på $18 \%$, hvilket er mer likt våre funn.

I vår studie fikk $6 \%$ av pasientene profylaktisk peroral antibiotikabehandling, mens dette ble gitt til $14 \%$ i en større undersøkelse fra USA (3). I denne studien fant de en infeksjonsrate på 3,5\%. Nesten halvparten av pasientene var imidlertid blitt kontrollert via telefonintervju, og da ble sårinfeksjon definert til bare å gjelde dem som hadde fått behandling med perorale antibiotika.

En av våre pasienter fikk peroral antibiotikabehandling på grunn av sårinfeksjon ved suturfjerning. Ingen fikk antibiotikaholdig salve $i$ forebyggende hensikt, men to pasienter fikk slik behandling på grunn av sårinfeksjon. Dette er i overensstemmelse med nasjonale retningslinjer for antibiotikabehandling $i$ allmennpraksis, der det er anbefalt å være restriktiv i bruk av lokalbehandling med antibiotika (11).

Vi benyttet en klinisk alvorlighetsgradering av sårinfeksjoner. Denne graderingen er validert i amerikanske studier $(3,4)$, men er ikke blitt validert i norsk oversettelse eller under norske forhold. Skillet mellom normal inflammasjon rundt suturer og grad 1-sårinfeksjon er vanskelig. Centers for Disease Control and Prevention i USA, som overvåker sykehusinfeksjoner, fraråder å betegne pustler og lett rubor rundt suturer som infeksjon (12).

Hos tre pasienter med slike pustler og lett rubor (grad 1-infeksjon) fikk vi oppvekst av rikelig mengde gule stafylokokkker fra sårkanten, men hos to ble det bare påvist normal hudflora. Dette kan selvfølgelig skyldes inadekvat prøvetaking, men funnet kan også representere en steril, ikke-infeksiøs lokal inflammasjon. Selv om bakteriell vekst ikke nødvendigvis må være til stede for å indikere en klinisk sårinfeksjon, hadde totalt seks av disse pasientene rikelig vekst av
Tabell 2 Andel sårinfeksjon etter pasientens kjønn, alder og sårfaktorer i 97 sår suturert ved Bergen legevakt i perioden februar til juni 2011

\begin{tabular}{|c|c|c|}
\hline Variabler & $\begin{array}{c}\text { Antall } \\
\text { sår }\end{array}$ & $\begin{array}{l}\text { Prosentandel } \\
\text { sårinfeksjon } \\
\text { (95\% KI) }\end{array}$ \\
\hline
\end{tabular}

$\begin{array}{lll}\text { Kjønn } & \\ \text { Kvinne } & 32 & 25(9-41) \\ \text { Mann } & 65 & 11(3-19)\end{array}$

\begin{tabular}{|c|c|c|}
\hline \multicolumn{3}{|c|}{ Alder (år) } \\
\hline$<65$ & 89 & $16(8-23)$ \\
\hline$\geq 65$ & 8 & $13(0-42)$ \\
\hline
\end{tabular}

\section{Tid fra skade}

til sutur (t)

$\begin{array}{lll}<3 & 67 & 18(9-28) \\ \geq 3 & 30 & 10(0-21)\end{array}$

\begin{tabular}{|c|c|c|}
\hline \multicolumn{3}{|c|}{ Sårlengde $(\mathrm{cm})$} \\
\hline$<3$ & 40 & $18(5-30)$ \\
\hline$\geq 3$ & 57 & $14(5-23)$ \\
\hline
\end{tabular}

Forurenset sår
Nei
$\begin{array}{lll} & \\ \mathrm{Ja} & 46 & 14(4-24) \\ & 46-29)\end{array}$

Kronisk sykdom

$\begin{array}{ccc}\text { Nei } & 89 & 15(7-22) \\ \text { Ja } & 8 & 25(0-64)\end{array}$

Sårlokalisering

$\begin{array}{lcc}\text { Ansikt/hode } & 17 & 12(0-29) \\ \text { Ekstremiteter } & 80 & 16(8-25)\end{array}$

potensielt patogene bakterier fra sårkanten. Estimering av det reelle antallet sårinfeksjoner blir likevel noe usikker tatt i betraktning at to hadde normal hudflora, to manglet oppvekst av bakterier og fem ikke ble undersøkt med dyrkingsprøver.

Vi fant at signifikant flere menn enn kvinner pådro seg sårskader på sin arbeidsplass, noe som virker naturlig ettersom menn oftere har håndverksyrker der verktøy benyttes. Dette stemmer også med at yngre menn oftere skadet hendene på knivkutt.

I tidligere studier er det blitt påvist høyere infeksjonsrate i sårskader som er dype, 
brede og lange, som har ujevne sårkanter, synlig forurensning eller fremmedlegemer, $\mathrm{i}$ sår hos eldre og hos diabetikere (13-15). I vår studie hadde verken sårets lengde, hvor gammelt det var før det ble suturert, lokalisering på kroppen eller forurensning før det ble suturert noen signifikant sammenheng med forekomsten av sårinfeksjon. Dette kan skyldes at vårt studiemateriale var for lite til å kunne påvise eventuelle forskjeller.

Basert på anbefalinger i tidligere lærebøker og prosedyrebøker inkluderte vi ikke sårskader $\mathrm{i}$ ansikt $\mathrm{og}$ hode som var eldre enn 12 timer og sår med annen lokalisering som var eldre enn åtte timer $(9,16)$. Innen disse tidsrammene vurderte vi om det var ulik infeksjonsrate i sår som ble suturert før det var gått tre timer og sår som ble suturert senere, men vi fant ingen slik forskjell. I nyere litteratur og litteraturgjennomganger er det satt spørsmålstegn ved om de gjeldende tidsrammene for tilrådelig primærlukking av traumatiske sårskader er godt nok dokumentert, og det hevdes at tidsgrensene for enkelte typer traumatiske hudsår sannsynligvis kan utvides uten at infeksjonsfaren øker $(10,17)$.

Skadepanoramaet $\mathrm{i}$ vår studie er preget av at sårskadene vi inkluderte ble behandlet på dag- og kveldstid. Sårskader behandlet om natten ble ekskludert, noe som nok medførte at visse traumatiske sårtyper forårsaket av vold og under ruspåvirkning ble underrepresentert. 20 av 102 pasienter møtte ikke til suturfjerning ved Bergen legevakt, men de ble oppringt og vi fikk kontakt med 15. Selv om artikkelforfatteren spurte etter objektive tegn på sårinfeksjon, er det en svakhet at vurderingen av infeksjonsgrad er basert på pasientens egenrapporterte funn og at telefonintervjuet kom $\mathrm{i}$ etterkant av suturfjerningen.

En annen svakhet ved studien er det lave antallet deltakere. Dette har gjort det vanskelig å påvise signifikante forskjeller.

\section{Konklusjon}

I denne studien fant vi at det i nesten ett av seks suturerte sår på legevakt oppsto klinisk sårinfeksjon. Det ble tatt bakteriologisk prøve av to tredeler av disse og påvist rikelig vekst av penicillinresistente gule stafylokokker i halvparten.

Akutt sårbehandling utføres i stort omfang på legevakter og hos fastleger. På samme måte som innen de kirurgiske disipliner er det viktig at også primærhelsetjenesten kartlegger sårskader og egne behandlingsresultater.

Vår studie har begrenset omfang. Det er ønskelig med flere liknende, men helst større og mer robuste norske studier der man vurderer utfallet etter sårbehandling i allmennpraksis og på legevakt. Slike bakgrunnsdata er viktige for å gi oss et bedre grunnlag for å kunne gjøre forbedringer og eventuelt korrigerende tiltak i vår sårbehandling.

\section{Christina Brudvik (f. 1962)}

er ph.d., førsteamanuensis, spesialist i allmennmedisin og fastlege. Hun forsker på ulike skader og skadebehandling og er fagansvarlig for undervisningen i småkirurgi ved legevakten. Forfatter har fylt ut ICMJE-skjemaet og oppgir ingen interessekonflikter.

\section{Hina Tariq (f. 1988)}

er kommunelegevikar.

Forfatter har fylt ut ICMJE-skjemaet og oppgir

ingen interessekonflikter.

\section{Soosaipillai V. Bernardshaw (f. 1959)}

er ph.d., spesialist i gastroenterologi og i generell kirurgi og overlege.

Forfatter har fylt ut ICMJE-skjemaet og oppgir ingen interessekonflikter.

\section{Knut Steen (f. 1955)}

er dr.med., spesialist i allmennmedisin og overlege.

Forfatter har fylt ut ICMJE-skjemaet og oppgir ingen interessekonflikter.

\section{Litteratur}

1. Adriaenssens N, Coenen S, Versporten A et al. European Surveillance of Antimicrobial Consump- tion (ESAC): quality appraisal of antibiotic use in Europe. J Antimicrob Chemother 2011; 66 (suppl 6): vi71-7.

2. Folkehelsinstituttet. Antibiotikaresistens og antibiotikabruk. www.fhi.no/eway/default.aspx?pid= 239\&trg=Content_6493\&Main_6157=6287:0: 25,5499\&MainContent $6287=6493: 0: 25,6832 \&$ Content_6493=6441:100352::0:6446:8:::0:0 (11.3.2015)

3. Hollander JE, Singer AJ, Valentine S et al. Wound registry: development and validation. Ann Emerg Med 1995: 25: 675-85.

4. Dire DJ, Coppola M, Dwyer DA et al. Prospective evaluation of topical antibiotics for preventing infections in uncomplicated soft-tissue wounds repaired in the ED. Acad Emerg Med 1995; 2: 4-10.

5. Lammers RL, Hudson DL, Seaman ME. Prediction of traumatic wound infection with a neural network-derived decision model. Am J Emerg Med 2003; $21: 1-7$.

6. Smack DP, Harrington AC, Dunn C et al. Infection and allergy incidence in ambulatory surgery patients using white petrolatum vs bacitracin ointment. A randomized controlled trial. JAMA 1996; 276: $972-7$

7. Diehr S, Hamp A, Jamieson B et al. Clinical inquiries. Do topical antibiotics improve wound healing? J Fam Pract 2007; 56: 140-4.

8. Eriksen H, Løver H, Madsen T et al. Overvåking av sykehusinfeksjoner. NOIS 2006, oppdatert 2013. www.fhi.no/om-fhi/a-aa-finn-frem/hjelp (11.3.2015)

9. Legevakthåndboken. 3. utg. 2005 843-89 www.lvh.no/ (11.3.2015)

10. Steen K. Bør traumatiske hudsår lukkes innen åtte timer? Tidsskr Nor Legeforen 2014; 134: 1657-60

11. Lindbæk M, Eliassen KE, Jensen S. Nasjonale faglige retningslinjer for antibiotikabruk i primærhelsetjenesten. Oslo: Helsedirektoratet, 2013.

12. Mangram AJ, Horan TC, Pearson ML et al. Guideline for prevention of surgical site infection, 1999 Am J Infect Control 1999; 27: 97-132.

13. Fernandez R, Griffiths R. Water for wound cleansing. Cochrane Database Syst Rev 2008; 1: CD003861

14. Maharaj D, Sharma D, Ramdass M et al. Closure of traumatic wounds without cleaning and suturing. Postgrad Med J 2002: 78: 281-2.

15. Hollander JE, Singer AJ, Valentine SM et al. Risk factors for infection in patients with traumatic lacerations. Acad Emerg Med 2001; 8: 716-20.

16. Boeckstyns M, Ebskov B, Ebskov LB. Skadestuekirurgi. 4. utg. København: Munksgaard, 2007.

17. Zehtabchi S, Tan A, Yadav K et al. The impact of wound age on the infection rate of simple lacerations repaired in the emergency department. Injury 2012; 43: 1793-8.

Mottatt 2.12. 2013, første revisjon innsendt 3.6. 2014, godkjent 11.3. 2015. Redaktør: Sigurd Høye. 